\title{
KONSUMSI AIR BERKORELASI DENGAN PERSEN LEMAK TUBUH REMAJA PUTRI DI KAWASAN PERDESAAN KABUPATEN BANYUMAS
}

\author{
Water Intake Correlates with Percent of Body Fat Adolescent Girlin Rural \\ Region,Banyumas District \\ Ibnu Zaki ${ }^{1}$, Hesti Permata Sari ${ }^{1}$, Farida ${ }^{1}$ \\ ${ }^{1)}$ Program Studi Ilmu Gizi, Fakultas Ilmu-Ilmu Kesehatan, Universitas Jenderal Soedirman \\ Ibnu_zaki28@yahoo.com
}

\begin{abstract}
This study aims to see the correlation of physical activity and water intake to body fat percent of adolescent girls. The cross-sectional conducted in three high school in rural areas Kedungbanteng District, Banyumas Regency. The number of respondents was 69 girls selected at random. Physical activity was measured by IPAQ questionnaires, and water intake used the Food record method while body fat percentage used Bioelectrical Impedance Analysis (BIA). Percent body fat category less 42.0\%, normal 39.1\%, high 18.8\%. Average physical activity 2592,38 $\pm 2120,74$ and water intake $879,80 \pm$ $304,53 \mathrm{ml}$. There was a correlation between water intake and body fat percentage whereas physical activity was uncorrelated.
\end{abstract}

Keyword : Physical Activity, Water Intake, Young Women

\begin{abstract}
Abstrak
Penelitian ini bertujuan untuk melihat korelasi aktifitas fisik dan asupan air terhadap persen lemak tubuh remaja putri. Metode yang digunakan adalah cross-sectional yang dilakukan di tiga SMA/MA/SMK di wilayah perdesaan Kecamatan Kedungbanteng, Kabupaten Banyumas. Jumlah responden 69 remaja putri dipilih secara acak. Aktifitas fisik diukur dengan kuesioner $I P A Q$, dan asupan air menggunakan metode Food record sedangkan persen lemak tubuh menggunakan Bioelectrical Impedance Analysis (BIA).Persen lemak tubuh kategori kurang 42,0\%, normal 39,1\%, lebih 18,8\%. Rata-rata aktifitas fisik $2592,38 \pm 2120,74$ MET-menit/minggudan asupan air 879,80 $\pm 304,53 \mathrm{ml}$. Terdapat korelasi antara asupan air dengan persen lemak tubuh sedangkan aktifitas fisik tidak berkorelasi.

Konsumsi air terbukti berkorelasi dengan persen lemak tubuh. Korelasi bersifat negatif sehingga setiap kenaikan konsumsi air dapat menurunkan persen lemak tubuh. Aktifitas fisik tidak berkorelasi dengan persen lemak tubuh.

Kata Kunci : Asupan Air, Aktifitas Fisik, Remaja Putri
\end{abstract}




\section{PENDAHULUAN}

Prevalensi gizi lebih pada remaja di Indonesia terus meningkat setiap tahun. Riset kesehatan dasar melaporkan bahwa tahun 2010 prevalensi gizi lebih sebesar 1,4\% (Litbangkes, 2010). Angka tersebut meningkat pada tahun 2013 yaitu 5,7\% (Balitbang Kemenkes, 2013). Hal serupa terjadi di Jawa Tengah dengan prevalensi gizi lebih tahun 2010 sebesar $0,7 \%$ meningkat menjadi $7,1 \%$. Berdasarkan karakteristik jenis kelamin prevalensi remaja putri lebih tinggi dari pada laki-laki yaitu 1,5\% dan 1,3\% dan meningkat pada tahun 2013 menjadi $8,1 \%$ dan 6,7\% (Balitbang Kemenkes, 2013).

Konsekuensi yang ditimbulkan akibat gizi lebih pada remaja putri akan berdampak jangka panjang dan memberikan efek negatif terhadap kesehatan di fase kehidupan selanjutnya. Hasil penelitian melaporkan bahwa remaja putri gizi lebih beresiko 4,6 kali lebih besar terjadi gangguan toleransi glukosa (Astuti, Prawirohartono, Noormanto, \& Julia, 2016). Toleransi glukosa menjadi awal pemicu terjadinya diabetes melitus. Penelitian lain menyatakan bahwa gizi lebih berkaitan dengan gangguan ginjal (Bagby, 2004).
Case control studi di Denpasar menyatakan bahwa responden yang mengalami gizi lebih beresiko 6,3 kali lebih besar terhadap sindrom metabolik (Wiardani, 2011).

Faktor penyebab gizi lebih pada remaja putri adalah multifaktorial. Faktor genetik, peningkatan konsumsi makanan cepat saji (fast food), rendahnya aktivitas fisik, konsumsi air putih, faktor psikologis, status sosial ekonomi, program diet, pengaruh iklan, dan jenis kelamin merupakan faktor-faktor yang berkontribusi (Barasi, 2009). Studi kasus kontrol menyebutkan bahwa adanya hubungan antara asupan energi fast food total dengan obesitas $(\mathrm{p}<0,05)$. Konsumsi energi softdrink yang tinggi memiliki resiko 1,4 kali terhadap kejadian gizi lebih (Rafiony, Purba, \& Pramantara, 2015). Studi lain melaporkan salah satu penyebab kejadian gizi lebih adalah rendahnya aktifitas fisik remaja putri (Hanifah \& Nindya, 2012).

Salah satu faktor protektif kejadian gizi lebih adalah konsumsi air. Konsumsi air $500 \mathrm{ml}$ selam tiga kali waktu makan yang dikonsumsi 30 menit sebelum waktu makan dilaporkan menurunkan berat badan, Indeks masa tubuh dan persen lemak tubuh (V. A. Vij \& Joshi, 2013). Studi di Indonesia melaporkan konsumsi air putih 30 menit 
sebelum makan sebanyak $454 \mathrm{ml}$ selama lima minggu pada remaja putri dengan gizi lebih menurunkan persen lemak tubuh (Mulyasari, Muis, \& Kartini, 2015). Penurunan persen lemak tubuh melalui mekanisme peningkatan metabolic rate tubuh akibat konsumsi air sehingga meningkatkan jumlah pengeluaran energi (Boschmann et al., 2003).

Pemantauan status gizi lebih pada remaja dapat diketahui melalui pengukuran persen lemak tubuh. level persen lemak tubuh yang tinggi menggambarkan status gizi lebih. Aktifitas fisik dan konsumsi air putih di kaitkan berhubungan dengan persen lemak tubuh. Penelitian ini bertujuan untuk melihat korelasi antara aktifitas fisik, konsumsi air terhadap persen lemak tubuh.

Semakin meningkatnya prevalensi gizi lebih di wilayah perdesaan seperti yang dilaporkan dalam riset kesehatan dasar tahun 2013 yaitu 4,8\%, maka perlu dilakukan penelusuran faktor yang berkaitan dengan gizi lebih (Balitbang Kemenkes, 2013). Penelitian ini dilakukan untuk mengetahui prevalensi gizi lebih berdasarkan persen lemak tubuh dan korelasi aktifitas fisik serta konsumsi air pada remaja putri di wilayah perdesaan Kabupaten Banyumas.

\section{METODE}

\section{Desain, tempat, dan waktu}

Penelitian ini menggunakan metode Cross sectional yang dilaksanakan di Kecamatan Kedungbanteng, Kabupaten Banyumas pada Bulan April-Mei 2017.

\section{Jumlah dan cara pengambilan subjek}

Subjek dalam penelitian ini berjumlah 69 remaja putri,berasal dari tiga sekolah SMA/MA/SMK di Kecamatan Kedungbanteng, Kabupaten Banyumas.Subjek dipilih secara random sesuai kriteria inklusi yang ditentukan yaitu remaja putri berusia 15-17 tahun, berdomisili di wilayah Kecamatan Kedungbanteng, bersedia terlibat dalam rangkaian penelitian dibuktikan dengan mengisi informed consent, dan diluar kriteria eksklusi. Kriteria eksklusi dalam penelitian ini adalah tidak mengisi logbook "Diary Makanku" dengan lengkap, logbook hilang, terdiagnosis penyakit kronis maupun infeksi tertentu pada saat penelitian, sakit sebelum atau selama penelitian, dan sedang menjalani diet tertentu.

\section{Jenis dan cara pengumpulan data}

Data yang dikumpulkan secara primer meliputi aktifitas fisik, konsumsi air dan persen lemak tubuh. Aktifitas fisik dikumpulkan dengan instrumen kuesioner IPAQ. Konsumsi air subjek 
diperoleh dari hasil pencatatan (estimated food records) selama 7 hari, dengan logbook "Diary Makanku”. Setiap subjek diberikan satu buah logbook dan wajib menuliskan setiap item makanan ataupun minuman yang mereka konsumsi beserta waktu, porsi, bahan, dan metode pengolahannya. Data persen lemak tubuh dikumpulkan dengan alat bantu Bioelectrical Impedance Analysis (BIA) dengan tingkat ketelitian $0,1 \mathrm{~kg}$.

\section{Pengolahan dan analisis data}

Analisis data diawali dengan pengujian statistik deskriptif yang bertujuan untuk mengetahui karakteristik data hasil penelitian. Stastistik deskriptif disajikan dalam bentuk jumlah dan persentase sesuai kategori tiap karakteristik. Kemudian dilanjutkan pengujian statistik analitik diawali dengan pengujian normalitas pada data aktifitas fisik, konsumsi air, dan persenlemak tubuhdengan uji Kolmogorov-Smirnov. Sebaran suatu data dinyatakan normal jika hasil uji menunjukan nilai $\mathrm{p}>0,05$. Untuk melihat korelasi antara aktifitas fisik, konsumsi air dengan persen lemak tubuh digunakan uji korelasi Pearson dengan alternatif pengujian Spearman. Penarikan kesimpulan atau uji hipotesis terhadap setiap hasil analisis statistik menggunakan tingkat kepercayaan 95\% $(\alpha=0,05)$. Hipotesis nol (HO) ditolak jika nilai $\mathrm{p}<0,05$. Data diolah menggunakan program SPSS 17.

\section{HASIL DAN PEMBAHASAN}

Gambaran karakteristik responden disajikan pada tabel 1. Sebanyak 69 remaja putri yang dipilih secara acak dari ketiga sekolah menengah atas (SMA/MA/SMK/Sederajat) yang berada diwilayah Kecamatan Kedungbanteng, Kabupaten Banyumas. Berdasarkan tabel 1 prosentase remaja putri gizi lebih sebesar $18,8 \%$. Hasil tersebut lebih tinggi dari prevalensi nasional tahun 2013 sebesar $8,1 \%$.Rata-rata aktifitas fisik remaja putri tergolong sedang $(62,3 \%)$. Sedangkan konsumsi air seluruhnya masih berada dalam kategori kurang (tabel 1).

Tabel 1. Karakteristik Responden

\begin{tabular}{lcc}
\hline Karakteristik & $\mathrm{n}$ & $\%$ \\
\hline Persen lemak tubuh & & \\
Kurang & 29 & 42,0 \\
Normal & 27 & 39,1 \\
Lebih & 13 & 18,8 \\
Aktifitas Fisik & & \\
Ringan & 8 & 11,6 \\
Sedang & 43 & 62,3
\end{tabular}


0

Jumlah presentase persen lemak tubuh hasil penelitian ini lebih rendah dibanding penelitian sebelumnya yaitu sebuah studi pada remaja putri berusia 13-15 tahun di wilayah desa menyatakan bahwa $32 \%$ remaja didesa tergolong melebihi normal(Handayani, Dwiriani, \& Riyadi, 2013). Studi lain melaporkan bahwa $14,3 \%$ remaja yang sudah menstruasi memiliki persen lemak tubuh lebih dari normal (Christianti \& Khomsan, 2012). Hasil peneitian ini lebih tinggi dibanding dengan sebuah studi cross sectional pada siswi SMP Pangudi Luhur Domenico Savio Semarang yaitu $12,5 \%$ persen lemak tubuh responden tergolong melebihi normal(Habibaturochmah \& Fitranti, 2014).

Rata-rata persen lemak tubuh pada penelitian ini $23,61 \pm 4,63 \%$. Hasil tersebut lebih tinggi dibanding laporan sebelumnya bahwa rata-rata persen lemak tubuh remaja putri umur $15.46 \pm 1.34$ tahun adalah $13.8 \pm 5.8 \%$ (Kerruish et al., 2002). Namun jika dibanding laporan lain hasil tersebut lebih rendah yaitu rata-rata persen lemak tubuh pada ketiga kelompok remaja yaitu kontrol sebesar

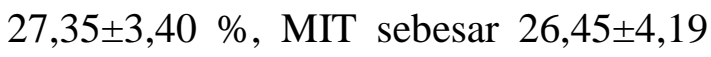

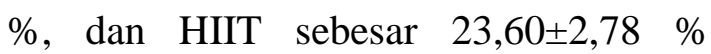
(Komala, Riyadi, \& Setiawan, 2016).

Remaja putri pada penelitian ini sebagian besar memiliki aktifitas sedang. Hasil tersebut sejalan dengan studi yang dilakukan di Semarang bahwa $47 \%$ subjek memiliki tingkat aktifitas yang sedang (Habibaturochmah \& Fitranti, 2014). Penelitian cross sectional yag dilakukan di SMA Kesatrian 1 Semarang juga melaporkan bahwa 53\% aktifitas fisik responden tergolong sedang-berat (Aini, 2014).

Hasil penelitian ini tidak sejalan dengan penelitian - penelitian sebelumnya. Aktifitas fisik remaja putri pada subjek penelitian yang dilakukan oleh nurul et al. 80\% tergolong ringan (Hanifah \& Nindya, 2012). Hal yang sama juga disampaikan oleh Wulandari et al. Bahwa sebagian besar responden remaja SMP memiliki aktifitas ringan (Wulandari \& Ungsianik, 2013).

Tabel 2 menunjukan bahwa konsumsi air remaja putri berkorelasi dengan persen lemak tubuh $(p<0,05)$.Korelasi yang didapat ialah korelasi negatif $(\mathrm{r}-0,313)$ artinya bahwa 
peningkatan konsumsi air akan menurunkan persen lemak tubuh, namun demikian korelasi yang dihasilkan pada penelitian ini adalah korelasi
lemah(Dahlan, 2011). Hal sebaliknya terjadi pada aktifitas fisik yaitu tidak terdapat korelasi yang bermakna terhadap persen lemak tubuh (tabel 2).

Tabel 2. Korelasi aktifitas fisik, asupan air dengan persen lemak tubuh

\begin{tabular}{lccc}
\hline \multirow{2}{*}{ Variabel } & \multirow{2}{*}{ Rerata \pm SD } & \multicolumn{2}{c}{ Persen lemak } \\
\cline { 3 - 4 } & & r & $\boldsymbol{p}$ \\
\hline Aktifitas Fisik (MET-menit/minggu) & $2592,38 \pm 2120,74$ & $-0,121$ & 0,323 \\
Konsumsi Air (ml) & $879,80 \pm 304,53$ & $-0,313$ & $0,009^{\mathrm{a}}$ \\
\hline
\end{tabular}

a. sigfikansi 0,05

Hasil ini sejalan dengan penelitian sebelumnya bahwa terdapat hubungan signifikan antara tingkat kecukupan konsumsi air dengan persen lemak tubuh $(p<0,05)$ (Habibaturochmah \& Fitranti, 2014). Studi eksperimen selama lima minggu dengan pemberian air putih 30 menit sesaat sebelum makan sebanyak $454 \mathrm{ml}$ pada remaja putri dapat menurunkan persen lemak tubuh (Mulyasari et al., 2015).Studi lain melaporkan bahwa pemberian air putih 1,5 liter selama 8 minggu terbukti menurunkan lemak tubuh (V. A. K. Vij \& Joshi, 2014).

Tabel 3. Pengaruh konsumsi air terhadap persen lemak tubuh

\begin{tabular}{lccc}
\hline \multirow{2}{*}{ Variabel Prediktif } & \multicolumn{3}{c}{ Regresi linier sederhana } \\
\cline { 2 - 4 } & $\beta$ & $\boldsymbol{p}$ & $\mathbf{R}^{\mathbf{2}}$ \\
\hline Konsumsiair & $-0,005$ & 0,009 & 0,098
\end{tabular}

$$
\beta \text { : koefisien regresi }
$$

meningkat mulai 10 menit awal setelah

Mekanisme penurunan persen lemak tubuh melalui konsumsi air putih mulai dilaporkan pada tahun 2003. Sebuah studi eksperimen dilakukan dengan pemberian $500 \mathrm{ml}$ air putih pada responden, hasilnya bahwa pemberian $500 \mathrm{ml}$ air meningkatkan metabolic rate sebesar $30 \%$. Peningkatan metabolic rate konsumsi air, dan puncak peningkatan pada rentang waktu 30-40 menit, efeknya akan bertahan selama satu jam. Studi ini juga menyatakan konsumsi 1,5 liter akan meningkatkan pengeluaran energi harian sekitar 200 Kkal (Boschmann et al., 2003)(V. A. Vij \& Joshi, 2013). Dengan 
meningkatnya metabolic rate maka meningkatkan pengeluaran energi, sebagai manifestasi peningkatan metabolic rate dan di lain sisi asupan energi kurang maka akan memicu proses glukoneogenesis yaitu pembentukan energi yang berasal dari simpanan lemak dampaknya cadangan lemak/lemak tubuh akan berkurang(Mahan, Escott-Stump, \& Krause, 2007).Hasil analisis regresi linier sederhana menyatakan bahwa konsumsi air menyumbang penurunan persen lemak tubuh sebanyak 9,8\%. Kenaikan konsumsi air $1 \mathrm{ml}$ dapat menurunkan persen lemak tubuh sebanyak 0,005\% (tabel 3).

Tingginya persen lemak tubuh remaja putri pada penelitian ini di mungkinkan karena dipengaruhi oleh jumlah konsumsi air yang tergolong kurang. Seluruh remaja putri dalam penelitian ini memiliki tingkat konsumsi air kurang dari kebutuhan. Kurangnya konsumsi air ini tidak luput dari peran remaja putri dalam pelaporan jumlah minuman yang dikonsumsi. Remaja putri dalam pelaporan tingkat konsumsi air memungkinkan terjadi underestimate, yaitu jumlah yang dilaporkan lebih rendah dari jumlah dikonsumsi meskipun peneliti telah melakukan pendampingan setiap dua hari sekali dalam pengisian food diary(Gibson, 2005).
Penelitian ini memaparkantidak ada korelasi antara aktifitas fisik dengan persen lemak tubuh. Berbeda dengan penelitian ini, sebuah penelitian menyatakan ada korelasi antara aktifitas fisik dengan persen lemak tubuh (Zanovec, Lakkakula, Johnson, \& Turri, 2009). Penelitian lain menyatakan hal lain bahwa terdapat hubungan bermakna antara durasi dan intensitas aktifitas fisik dengan persen lemak tubuh pada pria, namun tidak berhubungan pada remaja putri. Akan tetapi hasil berbeda jika dianalisis berdasarkan dua jenis kelamin, yaitu terdapat hubungan pada jenis kelamin wanita (Teo, Nurul-Fadhilah, Aziz, Hills, \& Foo, 2014).

\section{KESIMPULAN}

Konsumsi air terbukti berkorelasi dengan persen lemak tubuh. Korelasi bersifat negatif sehingga setiap kenaikan konsumsi air dapat menurunkan persen lemak tubuh hal ini berarti bahwa konsumsi air menjadi faktor protektif kenaikan persen lemak tubuh. Aktifitas fisik tidak berkorelasi dengan persen lemak tubuh.

\section{DAFTAR PUSTAKA}

Aini, S. N. (2014). Faktor risiko yang berhubungan dengan kejadian gizi lebih pada remaja di perkotaan. Unnes Journal of Public Health, 2(1).

Astuti, L. M. D., Prawirohartono, E. P., Noormanto, N., \& Julia, M. (2016). 
Obesitas sentral berhubungan dengan toleransi glukosa terganggu pada remaja perempuan. Jurnal Gizi Klinik Indonesia, 8(3), 113-117.

Bagby, S. P. (2004). Obesity-initiated metabolic syndrome and the kidney: a recipe for chronic kidney disease? Journal of the American Society of Nephrology, 15(11), 2775-2791.

Balitbang Kemenkes, R. I. (2013). Riset Kesehatan Dasar; RISKESDAS. Jakarta: Balitbang Kemenkes RI.

Barasi, M. E. (2009). At a glance ilmu gizi. Jakarta: Erlangga, 26-102.

Boschmann, M., Steiniger, J., Hille, U., Tank, J., Adams, F., Sharma, A. M., ... Jordan, J. (2003). Water-induced thermogenesis. The Journal of Clinical Endocrinology \& Metabolism, 88(12), 6015-6019.

Christianti, D. F., \& Khomsan, A. (2012). Asupan Zat Gizi Dan Status Gizi Pada Remaja Putri Yang Sudah Dan Belum Menstruasi. Jurnal Gizi Dan Pangan, 7(3).

Dahlan, M. S. (2011). Statistik untuk kedokteran dan kesehatan. Penerbit Salemba.

Gibson, R. S. (2005). Principles of nutritional assessment. Oxford university press, USA.

Habibaturochmah, \& Fitranti, D. Y. (2014). Hubungan Konsumsi Air, Asupan Zat Gizi, Dan Aktivitas Fisik Dengan Persen Lemak Tubuh Pada Remaja Putri. Journal of Nutrition College, 3(4), 595-603.

Handayani, M. S., Dwiriani, C. M., \& Riyadi, H. (2013). Hubungan Komposisi Tubuh Dan Status Gizi Dengan Perkembangan Seksual Pada Remaja Putri Di Perkotaan Dan Perdesaan. Jurnal Gizi Dan Pangan, 8(3), 181-186.

Hanifah, N., \& Nindya, T. S. (2012). Hubungan kontribusi beban glikemik makanan dan aktivitas fisik terhadap kejadian gizi lebih pada remaja di SMP full day Surabaya. Media Gizi Indonesia, 9(1).

Kerruish, K. P., O’Connor, J., Humphries, I. R. J., Kohn, M. R., Clarke, S. D., Briody, J. N., ... Baur, L. A. (2002). Body composition in adolescents with anorexia nervosa. The American Journal of Clinical Nutrition, 75(1), 31-37.

Komala, R., Riyadi, H., \& Setiawan, B. (2016). Latihan Intensitas Sedang Dan Berat Memperbaiki Vo2max, Indeks Massa
Tubuh, Dan Persen Lemak Tubuh Remaja Obes. Jurnal Gizi Dan Pangan, 11(3).

Litbangkes, B. (2010). Riset Kesehatan Dasar: Riskesdas 2010. Badan Litbangkes, Kementerian Kesehatan. Jakarta.

Mahan, L. K., Escott-Stump, S., \& Krause, M. V. (2007). Krause's food \& nutrition therapy. Elsevier Saunders.

Mulyasari, I., Muis, S. F., \& Kartini, A. (2015). Pengaruh asupan air putih terhadap berat badan, indeks massa tubuh, dan persen lemak tubuh pada remaja putri yang mengalami gizi lebih. Jurnal Gizi Indonesia, 3(2), 120-125.

Rafiony, A., Purba, M. B., \& Pramantara, I. D. P. (2015). Konsumsi fast food dan soft drink sebagai faktor risiko obesitas pada remaja. Jurnal Gizi Klinik Indonesia, 11(4), 170178.

Teo, P. S., Nurul-Fadhilah, A., Aziz, M. E., Hills, A. P., \& Foo, L. H. (2014). Lifestyle practices and obesity in Malaysian adolescents. International Journal of Environmental Research and Public Health, 11(6), 5828-5838.

Vij, V. A., \& Joshi, A. S. (2013). Effect of "water induced thermogenesis" on body weight, body mass index and body composition of overweight subjects. Journal of Clinical and Diagnostic Research: JCDR, 7(9), 1894.

Vij, V. A. K., \& Joshi, A. S. (2014). Effect of excessive water intake on body weight, body mass index, body fat, and appetite of overweight female participants. Journal of Natural Science, Biology, and Medicine, 5(2), 340.

Wiardani, N. K. (2011). I WJA Kejadian Sindrom Metabolik Berdasarkan Status Obesitas pada Masyarakat Perkotaan di Denpasar. Jurnal Ilmu Gizi, 2(2), 133-137.

Wulandari, S., \& Ungsianik, T. (2013). Status gizi, aktivitas fisik, dan usia menarche remaja putri. Jurnal Keperawatan Indonesia, 16(1), 55-59.

Zanovec, M., Lakkakula, A. P., Johnson, L. G., \& Turri, G. (2009). Physical activity is associated with percent body fat and body composition but not body mass index in white and black college students. International Journal of Exercise Science, 2(3), 175. 
J.Gipas, Mei 2018, Volume 2 Nomor 1 ISSN 2599-0152 eISSN 2599-2465

http://jos.unsoed.ac.id/index.php/jgps 